\title{
Oceanic and atmospheric patterns during spawning periods prior to extreme catches of the Brazilian sardine (Sardinella brasiliensis) in the southwest Atlantic
}

\author{
HELENA CACHANHUK SOARES ${ }^{1,2}$, LUCIANO PONZI PEZZI ${ }^{1,2}$, \\ DOUGLAS FRANCISCO MARCOLINO GHERARDI ${ }^{2}$ and EDUARDO TAVARES PAES ${ }^{3}$ \\ ${ }^{1}$ Center for Weather Forecast and Climate Studies (CPTEC). \\ ${ }^{2}$ Remote Sensing Department (DSR), National Institute for Space Research (INPE), Avenida dos Astronautas 1758, \\ São José dos Campos, SP, 12227-010 Brazil. E-mail: luciano@ dsr.inpe.br \\ ${ }^{3}$ Instituto Socioambiental e dos Recursos Hídricos (ISARH) \\ Universidade Federal Rural da Amazônia (UFRA) Belém, PA, Brazil.
}

\begin{abstract}
SUMMARY: Relative maxima and minima of landings of Brazilian sardine captured in the Southeast Brazil Bight (SBB) were compared with oceanic and atmospheric composites relative to the spawning period in December and January, prior to these landings. Atmospheric and oceanic variables such as wind stress, Ekman transport, mixing index, sea surface temperature (SST), precipitation, outgoing long wave radiation and geopotential height were analyzed, revealing distinct climatological patterns in the SBB for these extreme catches that have not been described before. The system could be characterized by cooler SST composite anomaly (SSTA) along the SBB as a response to increased cloud cover and reduced incidence of short-wave radiation, predominating one year before the Brazilian sardine catch maxima. This system can take on a different configuration in which positive SSTA condition in the SBB is associated with a less intense South Atlantic Convergence Zone displaced southwards one year before the period of minimum catch. Our results indicate that the spatial structure of the spawning habitat is influenced by specific ocean-atmosphere interactions rather than simply resulting from the choice of a stable environment. This climatic constraint strongly affects the interannual variability of the Brazilian sardine production.
\end{abstract}

Keywords: Brazilian sardine, southwest Atlantic climate, air-sea interaction, South Atlantic Convergence Zone, sea surface temperature, Southeast Brazil Bight.

RESUMEN: PATRONES OCEÁNICOS Y ATMOSFÉRICOS DURANTE PERÍODOS DE PUESTA PREVIOS A CAPTURAS EXTREMAS DE LA SARDINA BRASILERA (SARDINELLA BRASILIENSIS) EN EL OCÉANO ATLÁNTICO SUDOESTE. - Los desembarcos máximos y mínimos de capturas de la sardina brasileña en la Plataforma Sudeste Brasilera (SBB) se compararon con los patrones climáticos oceánicos y atmosféricos durante períodos de puesta, en diciembre y enero. Se analizó el comportamiento climático de variables oceanicas y atmosféricas como la influencia del viento, el transporte de Ekman, el índice de mezcla, la temperatura superficial del mar (SST), las precipitaciones, la radiación ascendente de ondas largas (OLR) y la altura geopotencial. Este análisis permitió la identificación de patrones climatológicos característicos sobre la SBB, no observados en trabajos previos. Los análisis revelaron que el sistema se caracteriza por SSTA más fríos sobre la sardina como respuesta a un incremento de la nebulosidad y la reducción de la incidencia de las radiaciones de onda corta, que predominan un año antes de las máximas capturas de sardina. Este sistema puede asumir una configuración distinta en la que SSTA positivos sobre la SBB se asocian con una SACZ desplazada hacia el sur un año antes del periodo de capturas mínimas. Nuestros resultados indican que la estructura espacial del hábitat de puesta es una consecuencia de las interacciones específicas océano-atmósfera, más que de una elección de ambiente estable y que ello influencia fuertemente la variabilidad interanual en la producción de sardina brasileña.

Palabras clave: sardina brasileña, clima del Atlántico sudoeste, interacción aire-mar, Zona de Convergencia del Atlántico Sur, temperatura superficial del mar, plataforma Sudeste Brasilera. 


\section{INTRODUCTION}

The Brazilian sardine Sardinella brasiliensis (Steindachner) is an important source of income for the Brazilian fishing industry and an accessible food item for the population because of its relatively low final cost. The Brazilian sardine stock is confined to the Southeast Brazil Bight, a highly productive semienclosed marine ecosystem extending from Cape Frio (Rio de Janeiro State, RJ) to Cape Santa Marta (Santa Catarina State, SC) (Fig. 1), where fishing activity is concentrated (Cergole, 1995). Landings peaked in 1973 at 225 thousand tons. The annual catches recorded at the Brazilian ports of Rio de Janeiro, Santos and Itajaí show a declining trend, with minimum catches in 2000 of around 20000 tons (Fig. 2). The reasons for the interannual variability of sardine catches are not yet understood and may involve overfishing, fluctuation in recruitment and spawning stock biomass and changes in the spawning habitat due to oceanic and atmospheric variability. The Brazilian sardine spawns at nightime along the SBB coast in waters shalower than $100 \mathrm{~m}$. Spawning occurs during the austral spring and summer and is more intense in December and January (Saccardo and Rossi-Wongtschowski, 1991). Recruitment occurs between June and August (Cergole, 1995) and the individuals become adult with lengths of around 16 and $17 \mathrm{~cm}$ at an age of around 1.5 years (Saccardo and Rossi-Wongtschowski, 1991). Catches by the purseseine fleet are generally confined to coastal areas in depths ranging from 30 to $50 \mathrm{~m}$ (Cergole and RossiWongtschowski, 2005).

The variability of biological production of marine resources is not a recent issue. Hjort, in 1914, stated that the variations of recruitment depend not only on food availability but also on winds and currents influencing displacement of fish outside their habitat. Cushing (1990) argued that the survival of individuals during the larval phase is dependent on the timing of food availability. Lasker (1975) and Cury and Roy (1989)

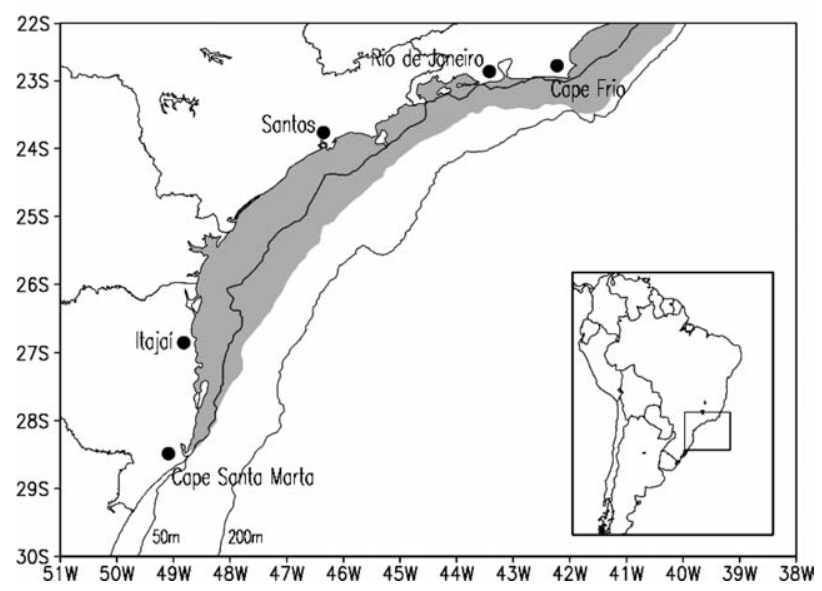

FIG. 1. - Spatial distribution of the Brazilian sardine stock along the southeast Brazil Bight (shaded area) and major landing ports (black dots). state that both food availability and concentration have a strong influence on the variability of fish populations. Ocean mesoscale retention processes are known to be responsible for keeping individuals in a favourable habitat during the initial phases of their life cycle (Sinclair, 1988). Bakun (1998) has summarized these theories and suggested the existence of three determinant factors for the survival of individuals in the first stages of their planktonic lives: enrichment (production), concentration and retention. Upwelling events are known to cause nutrient enrichment of surface waters and enhance productivity, whereas the retention of larvae is mainly related to local advection. Similarly, the concentration of material on oceanic fronts or due to water convergence and vertical stability can increase food availability. Summertime ocean dynamics over the SBB shelf is mainly influenced by wind stress and tidal mixing processes, whereas offshore the warm and salty Brazil region (Castro and Miranda, 1998) influences the shelf-break ocean dynamics. The main characteristic of this current is the coastal upwelling of the South Atlantic Central Water (SACW) that results from the combined effect of wind-driven offshore Ekman transport and the Brazil Current meander-induced shelfbreak upwelling (Campos et al., 2000). Other features such as coastline geometry and bottom topography also contribute to upwelling in the Southeast Brazilian coast (Rodrigues and Lorenzzetti, 2001).

The most important atmospheric systems that affect the SBB are the South Atlantic Subtropical High (SASH), the cold fronts and the South Atlantic Convergence Zone (SACZ). The SASH is a semi-permanent pressure centre that influences the wind pattern on the Brazilian coast, and causes the predominantly northeast wind direction in the SBB in summer (Pezzi and Souza, 2009). Cold fronts are typical features along the eastern coast of Brazil in the SACZ climatological region during this season (Cavalcanti and Kousky, 2009). The SACZ is a northwest-southeastoriented cloud band extending from the Amazon region to the southeast region of Brazil, which also affects the Atlantic Ocean. This system may last in this region for several days causing intense precipitation as high as $400 \mathrm{~mm} /$ month (Kodama, 1992). The SACZ is accompanied by a subtropical jet (a core of maximum winds in high levels of atmosphere), which flows between 20 and $35^{\circ} \mathrm{S}$ and has a low-level poleward flow prevailing along the western boundary of the subtropical highs (Kodama, 1993). Applying composite analysis, Pezzi and Cavalcanti (1994) found a region of maximum wind intensity anomaly at $200 \mathrm{hPa}$, covering a large portion of the western, southeastern and southern regions of Brazil. The location and occurrence of high-level jets express the thermal gradients between the poles and the Equator (Justi da Silva and Silva Dias, 2002).

In the upper atmosphere there are also two important systems: the Bolivian High, which is an intense anticyclone centred at $17^{\circ} \mathrm{S}, 65^{\circ} \mathrm{W}$ during the austral 

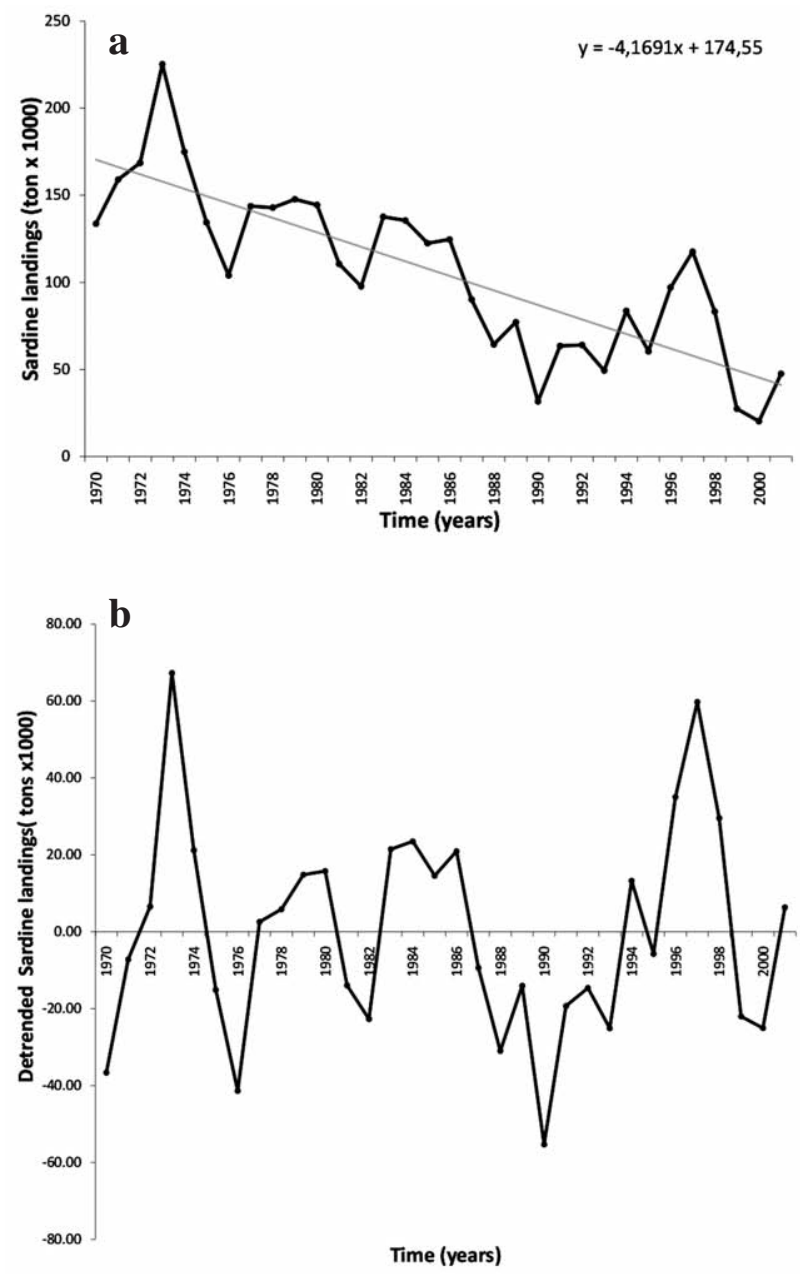

FIG. 2. - Total annual landings of the Brazilian sardine: a) linear trend in data; b) detrended time series.

summer (Virji, 1981); and the cyclonic circulation system (trough and vortices) localized over northeastern Brazil and frequently seen in December, January and February (Ramírez et al., 1999). The Bolivian High and the Northeast Trough are typical characteristics of the South American upper atmospheric summer circulation. Another atmospheric phenomenon that strongly impacts the south and southeast weather and climate patterns is atmospheric blocking. The atmospheric transient systems such as cold fronts can remain stationed when a blocking is formed, also causing a persistent weather condition. An atmospheric blocking is characterized by a rupture of zonal flow caused by an intense high pressure centre at high latitudes, which interrupts the eastward movement of the cyclones and anticyclones (Fuentes, 1996, Kayano, 1999). Several studies (Van Loon, 1956, Lejenäs, 1984, Trenberth and Mo, 1985, Kayano and Kousky, 1990, Sinclair, 1996) have identified Australia and New Zealand as the preferential blocking formation regions for the southern hemisphere, and the southwestern region of the Indian and Atlantic oceans as secondary preferential areas.
Previous studies have tried to establish an empirical relation between the ocean and atmosphere dynamics and the reproductive strategy of the Brazilian sardine. Bakun and Parrish (1990) investigated the climatology of sea surface temperature (SST), wind stress and wind mixing index, Ekman transport, solar radiation and cloud cover for the SBB. They suggested that this species prefer to spawn in places with low turbulent mixing and Ekman transport, conditions that are found in the inner area of the SBB, closest to the coast. In another study, Sunyé and Servain (1998) suggest that the seasonal landings of the Brazilian sardine are influenced by the cold and low salinity coastal water flowing along the inner shelf of the SBB. It has been also suggested that low wind velocity and the size of the spawning stock biomass are important factors influencing recruitment variability (Jablonski and Legey, 2004). Paes and Moraes (2007) discussed the influence of El Niño and La Niña events on the variability of the Brazilian sardine yields, and suggested that during El Niño episodes the Subtropical Jet is intensified, blocking the evolution of frontal systems and therefore affecting their reproductive habitat.

The present study builds upon the ideas of Bakun and Parrish (1990) and uses an improved environmental dataset to understand oceanic and atmospheric influences on the Brazilian sardine. The analyses are based on composites calculated for the spawning period previous to the events of low and high fish landings. Case studies characterized by landing maxima and minima were also evaluated. This integrated ocean and atmospheric approach linked to the extremes of Brazilian sardine catches has not been applied in previous studies. Therefore, our goal was to identify the atmosphere and oceanic characteristics and circulation patterns that influence oscillations in yield of Brazilian sardine.

\section{MATERIALS AND METHODS}

\section{Data set}

The sardine data set used consists of the total annual biomass landings (in metric tons) recorded between 1970 and 2001 at the main landing ports of Santos (SP), Rio de Janeiro (RJ) and Itajaí (SC), covering the three states where Sardinella braziliensis occurs. The landing data were recorded by the Brazilian Environmental Agency and are available at the Food and Agriculture Organization of the United Nations (FAO) site at http://www.fao.org/fishery/species/2090. These data are known to closely represent the major oscillation patterns observed in the sardine stock (Sunyé and Servain, 1998) and are hereafter referred to simply as sardine catches.

Cross-correlations performed on the estimated recruitment, spawning stock biomass and yield from data of Cergole et al. (2002) show that the spawning stock biomass correlates with the detrended Brazil- 
ian sardine landings ( $r=0.83, P<0.0001$, no lag) and responds to recruitment with a delay of one year $(r$ $=0.66, P=0.002)$. Therefore, the detrended Brazilian sardine landings data used here can be considered as an unbiased global estimate of sardine abundance and a surrogate for catch per unit effort (Sunyé and Servain, 1998). Estimates of the spawning stock biomass for the Brazilian sardine (Cergole, 1995, Cergole et al., 2002) using virtual population analysis (Quinn and Deriso, 1999) were based on otolith data, monthly landings of the commercial fishing fleet collected from 1977 to 1997, frequency distributions of length in controlled catches and two acoustic surveys carried out in 1995 . Their findings show that from 1977 to 1986 and from 1991 to 1995 the average estimated spawning stock biomass was 301000 and $345000 \mathrm{t}$, respectively. The average estimated recruitment for these two periods was 18 and 24.15 billion units, respectively. In contrast, from 1986 to 1990 the average estimated spawning stock biomass was only around $168500 \mathrm{t}$, and the average estimated recruitment was only 10.35 billion units. In fact, the Brazilian sardine fisheries collapsed in the late 1980s and early 1990s, possibly because of both fishing and adverse environmental conditions (Cergole et al., 2002).

The atmospheric analysis was made using monthly mean fields of geopotential height and wind vector components covering the period 1970 to 2001 . These fields were mapped onto a uniform $1.125 \times 1.125^{\circ}$ (latitude $\times$ longitude) grid derived from the European Centre for Medium-Range Weather Forecasts ReAnalysis-40 (ERA-40) project. ERA-40 was processed with the inclusion of a large amount of meteorological information from ground and upper air stations, satellites, ocean buoys and data collected from automatic platforms (Uppala et al., 2005). The wind stress used here has a spatial resolution of $0.5 \times 0.5^{\circ}$ (latitude $\mathrm{x}$ longitude). This wind stress is the same used in the Simple Ocean Data Assimilation (Carton and Giese, 2005), an oceanic reanalysis database generated using a numerical general ocean circulation model corrected by in situ and satellite observations (Carton and Giese, 2005). The monthly SST data set has a spatial resolution of $2 \times 2^{\circ}$ (latitude $x$ longitude), extends from 1970 to 2001 and was obtained from the third version of the Extended Reconstruction of Global Sea Surface Temperature (ERSST.v3) (Smith et al., 2008). The precipitation data set originated from a mix of satellite and ground station data available in the Global Precipitation Climatology Project (GPCP) (Adler et al., 2003). The GPCP has a spatial resolution of $2.5 \times 2.5^{\circ}$ (latitude $\times$ longitude) and spanned the period from 1979 to 2002 . The outgoing long wave radiation (OLR) information comes from National Oceanic and Atmospheric Administration (NOAA) satellites and the data set used here has a spatial resolution of $2.5^{\circ} \times 2.5^{\circ}$ (latitude $\mathrm{x}$ longitude) extending from 1974 to 2006 (Liebmann and Smith, 1996).

\section{Methodology}

The climatologies were calculated through the monthly averages of December and January for the 1970-2001 base period for the following variables: wind stress, zonal wind velocity at $250 \mathrm{hPa}$, mixing index, Ekman transport, SST and geopotential height. For OLR and precipitation the base periods were 19742001 and 1979-2001, respectively. Ekman transport and mixing index were computed from wind stress $(\vec{\tau}$, $\mathrm{kg} \mathrm{m}^{-1} \mathrm{~s}^{-2}$ ), defined as:

$$
\vec{\tau}=\rho C_{D} \vec{w}^{2},
$$

where $\vec{w}$ is the wind velocity, $\rho$ is the air density (1.22 $\mathrm{kg} \mathrm{m}^{-3}$ ), and $C_{D}$ is the drag coefficient, 0.0013 .

Then, Ekman transport $\left(\mathrm{kg} \mathrm{m}^{-1} \mathrm{~s}^{-1}\right)$ is calculated as follows:

$$
\vec{E}=\vec{k} \times \frac{\vec{\tau}}{f}
$$

where $\vec{k}$ is a unit vector directed vertically upward, and $f$ is the coriolis parameter $\left(\mathrm{s}^{-1}\right)$.

The mixing index (MI, see Bakun and Parrish, 1990) is defined as the rate that wind transfers mechanical energy to the ocean and produces turbulent mixing in the water column. This index is proportional to the third power of the wind speed $\left(\mathrm{m}^{3} \mathrm{~s}^{-3}\right)$ :

$$
M I \approx\left(\sqrt{\frac{\vec{\tau}}{\rho C_{D}}}\right)^{3}
$$

All composites were calculated with a lag of one year before the extreme catches occurred, assuming that about $80 \%$ of the Brazilian sardine captured by the trawler fleet is one year old (Matsuura, 1996). The composite fields for the periods of minimum and maximum catches were calculated by averaging the linearly detrended (Fig. 2) anomaly fields for December and January for each period. A threshold of 0.7 standard deviations was applied to the detrended catches to determine extreme catches, resulting in the selection of eight years of maxima and eight years of minima (Table 1). The complete cycle of two extreme low catches interspersed by one year of high catch was also analyzed separately as case studies: December 1991 and January 1992 (prior to the 1993 minimum), December 1995 and January 1996 (prior to the 1997 maximum), and December 1998 and January 1999 (prior to the 2000 minimum).

\section{RESULTS}

\section{Climatological patterns}

The wind stress climatology (Fig. 3a) had a northeast direction in the northern portion of the SBB, with 
TABLE 1. - Extreme Brazilian sardine catches and respective standard deviations.

\begin{tabular}{lccc}
\hline Maxima & SD & Minima & SD \\
\hline 1973 & 2.42 & 1970 & -1.32 \\
1974 & 0.76 & 1976 & -1.49 \\
1983 & 0.77 & 1982 & -0.81 \\
1984 & 0.84 & 1988 & -1.11 \\
1986 & 0.76 & 1990 & -2.00 \\
1996 & 1.26 & 1993 & -0.91 \\
1997 & 2.15 & 1999 & -0.79 \\
1998 & 1.07 & 2000 & -0.90 \\
\hline
\end{tabular}

the highest intensities between $20^{\circ} \mathrm{S}$ and $24^{\circ} \mathrm{S}$. This is related to the climatological position of the SASH identified in the low-level circulation field $(850 \mathrm{hPa})$ centred around $28^{\circ} \mathrm{S}$ and $10^{\circ} \mathrm{W}$ (Fig. 4a). The highpressure system induces intense northeasterly winds in the SBB region during the summer, as a consequence of the pressure gradient between the high pressure centre over the ocean and the lower pressure over the continent. This northeasterly wind is one of the factors that trigger the intense upwelling in the northern SBB, which is followed by an offshore Ekman surface transport seen in Figure 3b. The mixing index climatology shows an intense gradient within the SBB, with maximum mixing values to the north and lower values to the south (Fig. 3c). The SST (Fig. 3d) climatology indicates that the southern limit of warmer waters associated with the Brazil Current is positioned around $25^{\circ} \mathrm{S}$, but it fails to show the cold waters associated with the wind-driven upwelling in the SBB due to the reduced spatial resolution.

The circulation climatology of lower levels in Figure 4a shows the average position of the SASH and the airflow from the Amazon to the southeast region transporting humidity that contributes to the formation and maintenance of SACZ episodes. This is an important component of the South Atlantic Monsoon System (Carvalho et al., 2004) characterized by increased convective activity that starts over the northwest Amazon and progressively intensifies towards the SBB. In high levels of the atmosphere (Fig. 4b) the typical summer circulation is characterized by the presence of a trough over the Atlantic Ocean, with cyclonic circulation close to the northeast coast of Brazil and an anticyclonic circulation in the Bolivian High Centre, around $15^{\circ} \mathrm{S}$ and $65^{\circ} \mathrm{W}$. The maximum wind velocities occurred between $30^{\circ} \mathrm{S}$ and $50^{\circ} \mathrm{S}$, indicating the presence of a high level jet stream. The precipitation and OLR climatological fields (Fig. 4c and d) show the SACZ oriented from northwest to southeast with high precipitation (Fig. 4c) and low values of OLR (Fig. 4d). In the subtropical high pressure centres, South Pacific Sub-
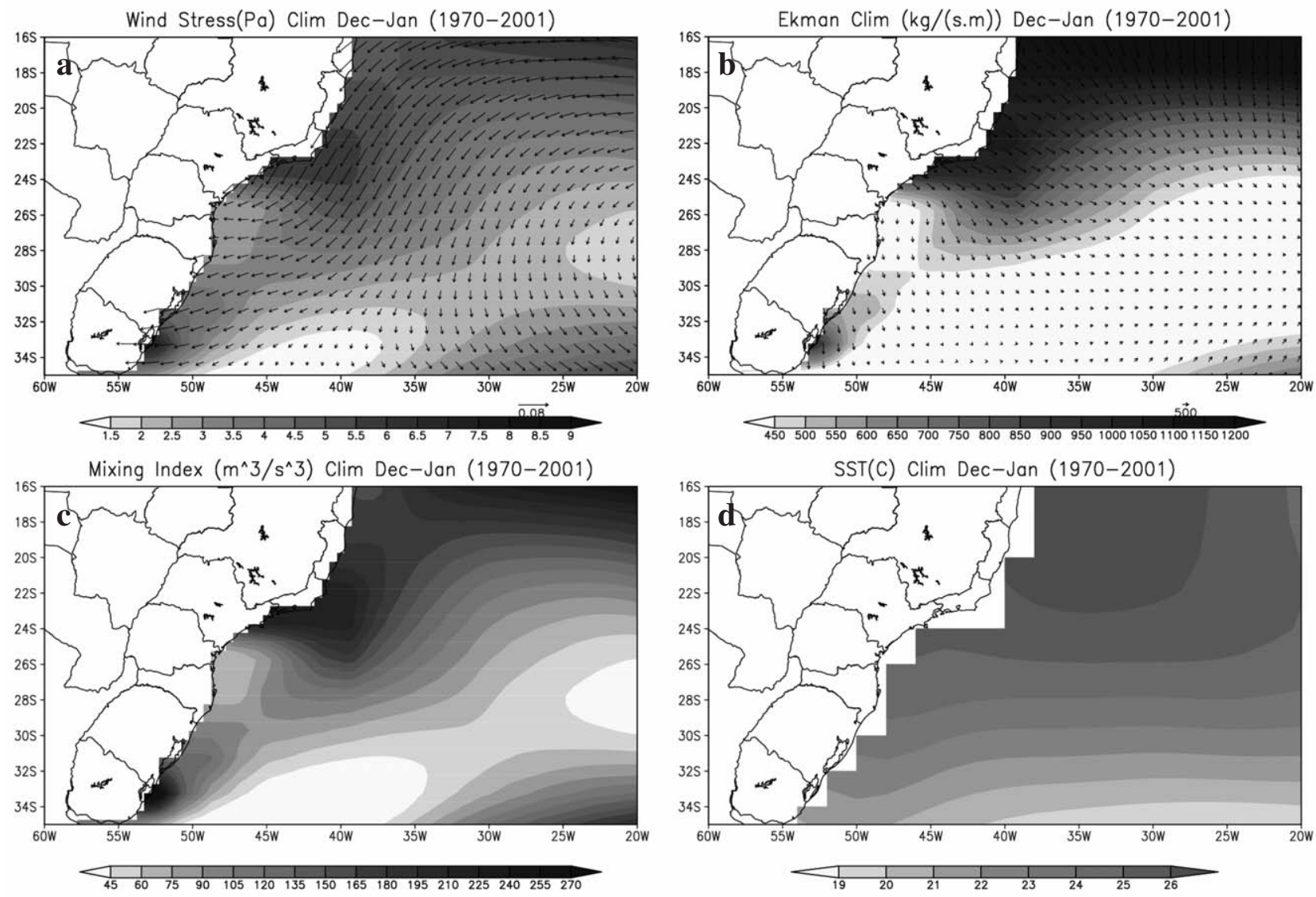

FIG. 3. - Climatology fields of: a) wind stress (Pa), vectors indicate direction (x 102); b) Ekman transport ( $\left.\mathrm{kg} \mathrm{s}^{-1} \mathrm{~m}^{-1}\right)$, vectors indicate direction; c) mixing index $\left(\mathrm{m}^{3} \mathrm{~s}^{-3}\right)$; d) sea surface temperature $\left({ }^{\circ} \mathrm{C}\right)$. 

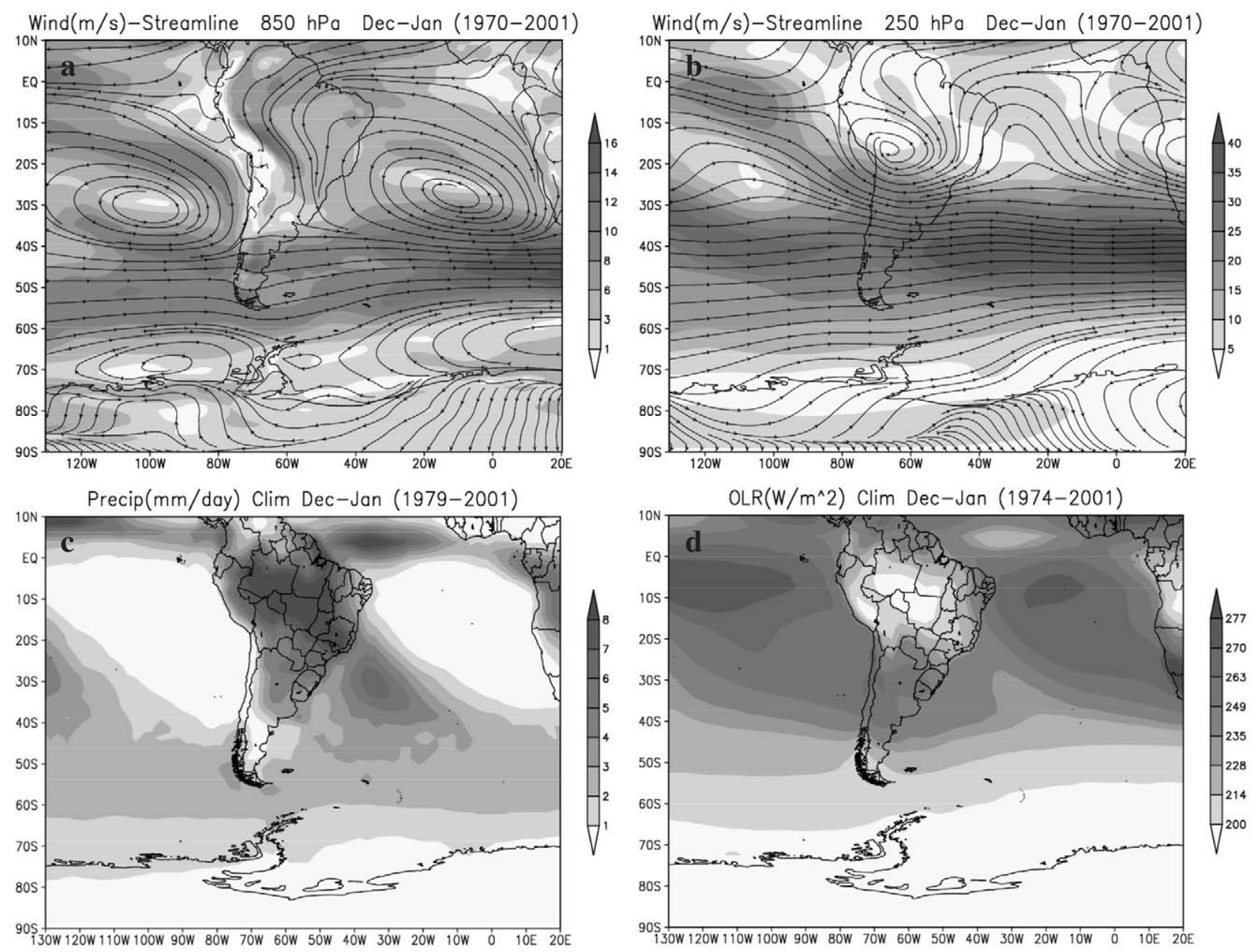

FIG. 4. - Climatology fields of: a) wind velocity $\left(\mathrm{m} \mathrm{s}^{-1}\right)$ and streamlines for $850 \mathrm{hPa}$; b) wind velocity $\left(\mathrm{m} \mathrm{s}^{-1}\right)$ and streamlines for $250 \mathrm{hPa}$; $)$ precipitation $(\mathrm{mm} /$ day $)$; d) outgoing long wave radiation $\left(\mathrm{W} \mathrm{m}^{-2}\right)$.

tropical High (SPSH) and SASH, high OLR values and low precipitation are observed because of the intense divergence in these centres.

\section{Composites}

Composites of the Ekman transport and the mixing index anomalies for the maximum catches show lower values in the northern half of the SBB, but the anomalies are higher for the period of minimum catches (Fig. $5 \mathrm{a}, \mathrm{b})$. The SST composite anomaly (SSTA) field shows a considerable contrast between maximum and minimum catches (Fig. 5). The maximum catches are associated with negative SSTA in the SBB and in a large part of the tropical and southern regions of the Atlantic Ocean, whereas the minimum catches are associated with positive SSTA. In the years of maximum sardine catches the zonal wind at $250 \mathrm{hPa}$ level shows an intense positive anomaly in the region between $20^{\circ}$ $\mathrm{S}$ and $30^{\circ} \mathrm{S}$, indicating that the Subtropical Jet is intensified (Fig. 6a). On the other hand, at lower levels ( 850 $\mathrm{hPa}$ ) the geopotential height indicates the presence of atmospheric blocking (Fig. 6c). This blocking pat- tern is evident due to the intense positive geopotential height anomaly in the south, centred at $60^{\circ} \mathrm{S}$ and $40^{\circ} \mathrm{W}$. In the same field it is possible to observe a negative anomalous region that covers the SBB, with a core in the southwest Atlantic Ocean. This pattern indicates that the pressure in this region was lower than the climatology, which is related to the intense cold frontal system activity (Fig. 6c). A low pressure centre in this region contributes to the maintenance of the SACZ through the humidity transport to the continent from the ocean. During the minimum sardine catches, the zonal wind anomaly at high levels lacks the subtropical jet configuration observed prior to the maximum sardine catches and the geopotential height field (Fig. 6) shows negative anomalies centred further to the north, at $35^{\circ} \mathrm{S}$ and $50^{\circ} \mathrm{W}$. This aspect is associated with the passage and permanence of frontal systems over this region. The OLR anomaly (OLRA) field associated with the maximum catches shows an intense negative anomaly in the SACZ climatological region (Fig. 6e) and this reflects increased cloudiness. During periods of minimum catches a positive OLRA is observed in the SACZ area, as shown in Figure 6f. 

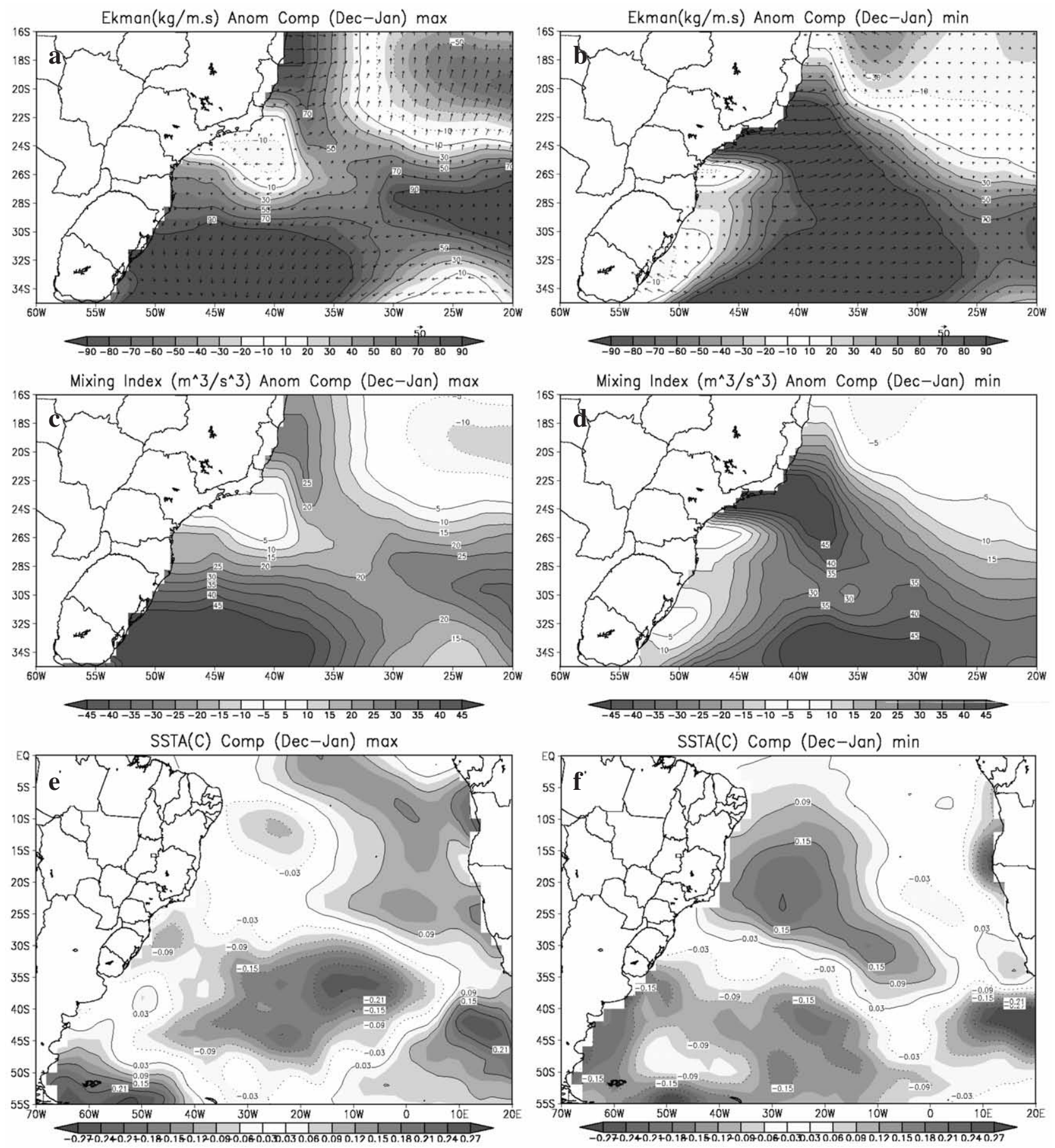

FIG. 5. - Anomaly composite fields of: a) Ekman transport for years prior to maximum catches, vectors indicate direction; b) Ekman transport for years prior to minimum catches, vectors indicate direction; c) mixing index for years prior to maximum catches; d) mixing index for years prior to minimum catches; e) sea surface temperature for years prior to maximum catches; $\mathrm{f}$ ) sea surface temperature for years prior to minimum catches. Dashed lines are negative anomaly values and continuous lines are positive anomaly values.

\section{Case studies}

The mixing index for the monthly averaged fields of December and January previous to the low catch year of 1993 shows higher positive anomalies for the north SBB (Fig. 7a). This characteristic agrees with what was observed in the composite analysis for the minimum catches, where an excess of mixing was identified for this region. In this case, wind stress and Ekman transport anomalies (not shown) have higher (lower) values in the north (south). Wind stress anomalies display a northeast direction with an anomalous offshore trans- 

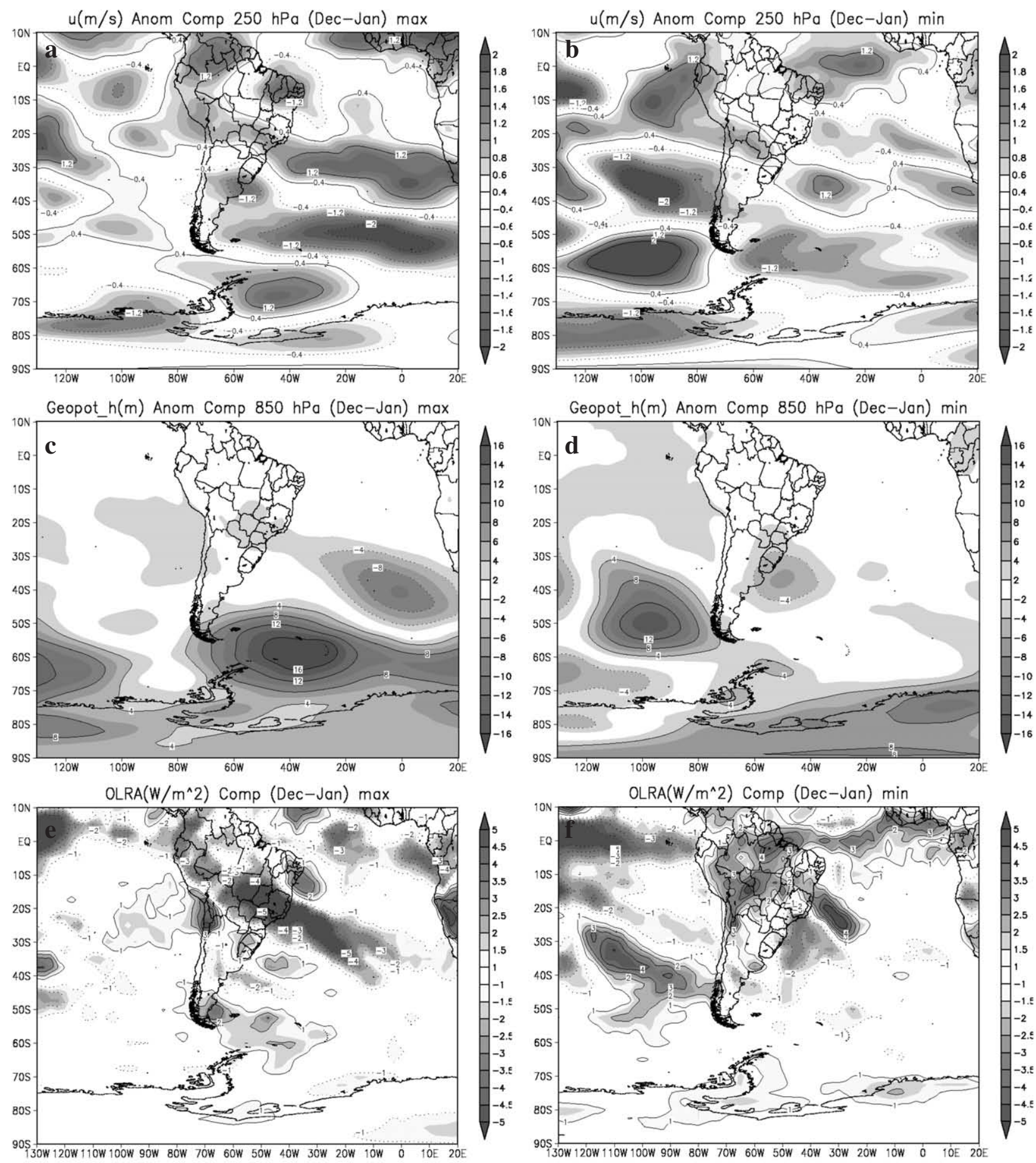

FIG. 6. - Anomaly composite fields of: a) zonal wind at $250 \mathrm{hPa}$ for maximum catch years; b) zonal wind at $250 \mathrm{hPa}$ for minimum catch years; c) geopotential height at $850 \mathrm{hPa}$ for maximum catch years; d) geopotential height at $850 \mathrm{hPa}$ for minimum catch years; e) outgoing long wave radiation for maximum catch years; f) outgoing long wave radiation for minimum catch years. Dashed lines are negative anomaly values and continuous lines are positive anomaly values.

port in the north region of the SBB. The analysis of the high catch in 1997 showed negative mixing in the inner region of the SBB and anomalies close to zero in the northern SBB (Figure 7c). The other low extreme event that occurred in 2000 (Fig. 7e) showed a similar behaviour to that of 1993, with an excess mixing index in the northern region of the SBB.

The precipitation analysis in the spawning period prior to 1993 showed strong negative anomalies over the north of Brazil and also in the SBB (Fig. 7b), 

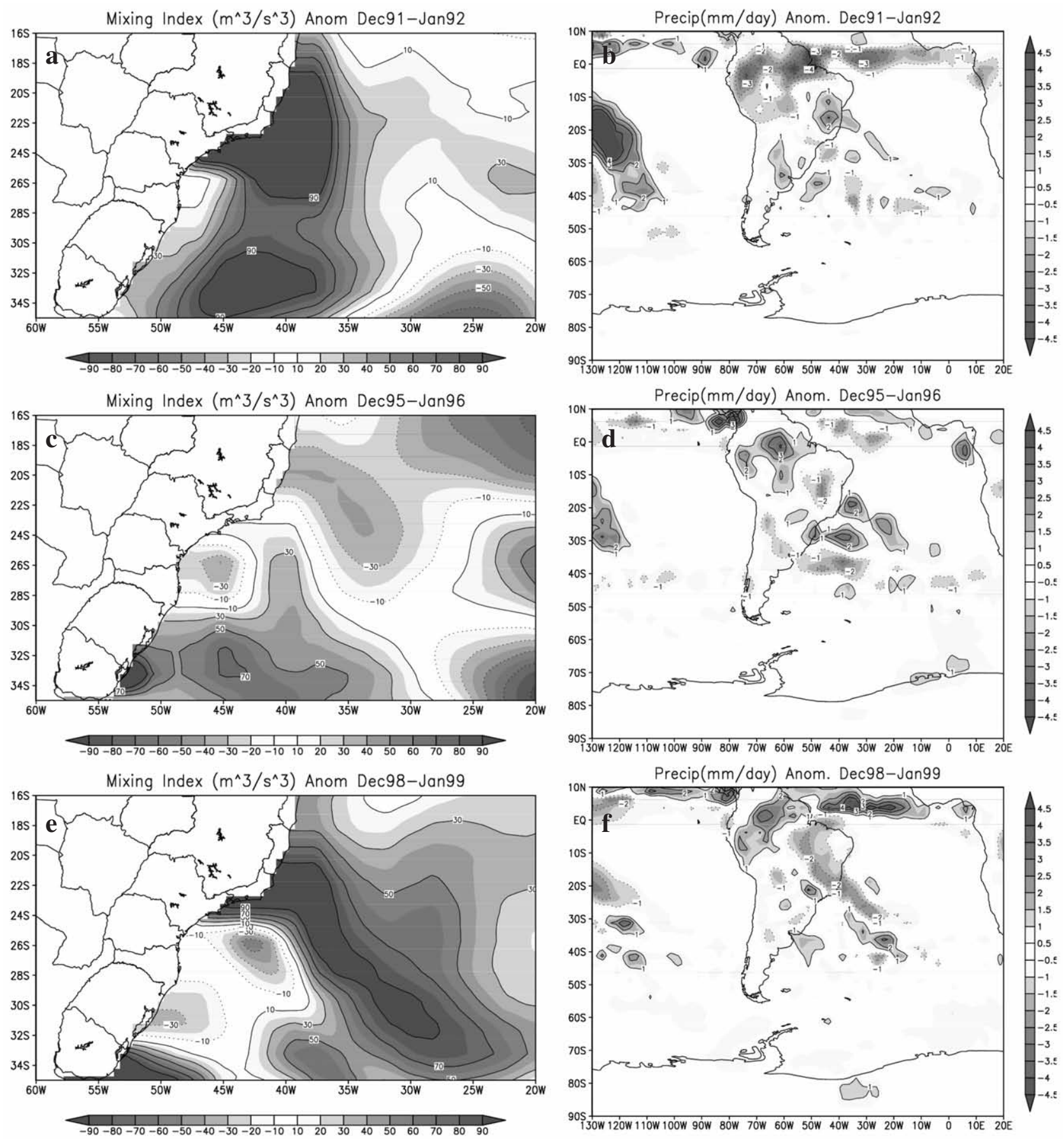

FIG. 7. - Anomaly fields for the case studies of: a) mixing index $\left(\mathrm{m}^{3} \mathrm{~s}^{-3}\right)$ December 1991 and January 1992; b) precipitation (mm day-1) December 1991 and January 1992; c) mixing index $\left(\mathrm{m}^{3} \mathrm{~s}^{-3}\right)$ December 1995 and January 1996; d) precipitation $\left(\mathrm{mm}^{-1} \mathrm{day}^{-1}\right)$ December 1995 and January 1996; e) mixing index $\left(\mathrm{m}^{3} \mathrm{~s}^{-3}\right)$ December 1998 and January 1999; f) precipitation (mm day $\left.{ }^{-1}\right)$ December 1998 and January 1999. Dashed lines are negative anomaly values and continuous lines are positive anomaly values.

suggesting that the SACZ was less active during this period. Looking at the years just before the maximum extreme catches, in December 1995 and January 1996 the precipitation anomaly field showed a positive sign in the northwest of South America and in the southwest Atlantic close to the SBB (Fig. 7d), indicating an intensification of the SACZ. Conversely, the precipitation anomaly field associated with the year 2000, when a minimum catch was recorded, shows negative values extending from the northwest to the southeast region. The northwest of South America showed an excess precipitation (positive anomalies) and in the SBB anomalies were close to zero, indicating that in these months the position of the precipitation band over the 

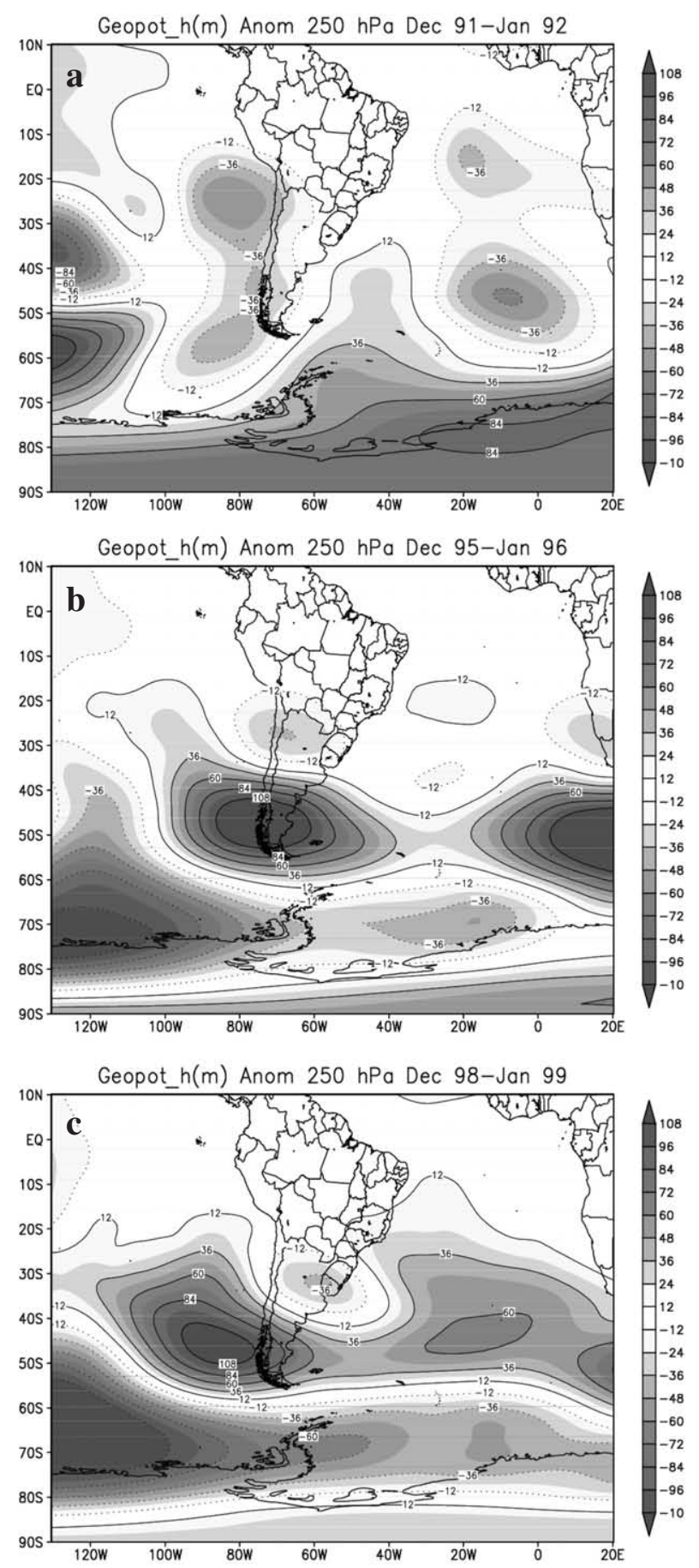

FIG. 8. - Anomaly fields for the case studies of: a) geopotential height (m) December 1991 and January 1992; b) geopotential height (m) December 1995 and January 1996; c) geopotential height (m) December 1998 and January 1999. Dashed lines are negative anomaly values and continuous lines are positive anomaly values.

SBB was close to the climatology (Fig. 7f). In summary, the SACZ intensification over the SBB was only detected prior to the maximum catch year.

In December, January and February the Northeast Trough is found at high levels as a typical climatological pattern of the atmospheric circulation in northeast Brazil. This system usually lies between $40^{\circ} \mathrm{W}$ and $20^{\circ} \mathrm{W}$ and 0 and $20^{\circ} \mathrm{S}$, as shown in Figure 4b. However, a striking feature was revealed by the geopotential height levels of the atmosphere for the case studies (Fig. 8). From December 1991 to January 1992 (Fig. 8a) a centre of negative anomalies appeared close to the Northeast Trough region, at approximately $20^{\circ} \mathrm{S}$ and $18^{\circ} \mathrm{W}$. In the spawning period previous to the maximum catch no anomalies in this region were detected (Fig. 8b). However in December 1998 and January 1999 (Fig. 8c), the geopotential height field showed intense positive anomalies in the region of the Northeast Trough. This pattern suggests that this system was less intense than the climatology in the spawning period previous to the year of minimum catch (2000). Brambilla et al. (2004) showed that when the SACZ is accompanied by upper troposphere cyclonical vortices over northeast Brazil the precipitation is more intense. Then the reduced activity of the Northeast Trough could be associated with a weaker SACZ presence that was observed in this low catch year.

\section{DISCUSSION}

The results presented here show strong evidence of the linkage between extreme events of Brazilian sardine catches and the ocean-atmosphere interaction in the southwest Atlantic, where thermodynamic feedback processes tend to be more important than dynamic processes (Chaves and Nobre, 2004). This feedback mechanism over the southwest Atlantic is characterized by a tendency for SSTA to be negative north of $40^{\circ}$ and positive to the south, following the interannual intensifications of the SACZ, as described by Robertson and Mechoso (2000). So, one year before the Brazilian sardine catch maxima, negative SSTA (Fig. 5e) was seen to predominate along the $\mathrm{SBB}$, evolving as a response to increased cloud cover (note the negative OLRA in Figure $6 \mathrm{e}$ ) and reduced incidence of short wave radiation (in the region of SACZ). During the summer months, when the SACZ occurs, it is enhanced and displaced to the north with negative SSTA observed south of $20^{\circ} \mathrm{S}$ and, conversely, it shifts southward followed by positive SSTA (Doyle and Barros, 2002). In the latter case, the wind-induced Ekman transport and mixing anomalies are near zero or slightly negative (Fig. 5a, c) since the typical northeastern winds are weaker as the western branch of the SASH tends to shift further north during such conditions. The predominance of strong negative SSTA (Fig. 5e) prior to maximum catches indicates that the spawning period is associated with colder than climatology surface waters. This colder water can be the result of an intensified SACZ (as identified in the precipitation and OLR anomaly fields) via reduced net radiative energy input into the ocean. Following a physical reasoning proposed in a numerical study performed by Chaves and Nobre (2004), the increased cloudiness (Fig. 6e) in the region is likely to be the cause of the ob- 
served lower SST values. In fact, Gigliotti et al. (2010) demonstrated that the spawning habitat of the Brazilian sardine expands over the SBB when the SSTA during the spawning period is zero or slightly negative, leading to increased sardine catches in the following year. In contrast, the spawning habitat contracts when SSTA is positive, leading to reduced sardine catches.

During positive SSTA conditions over the SBB, the SACZ tends to be displaced southwards, as indicated above, and it is less intense. This can be seen by comparing the larger geographical extent of negative OLRA for the period of maximum catch (Fig. 6e) with the reduced geographical extent for the period of minimum catch (Fig. 6f). It is also easy to see in the examples of the case studies that precipitation is higher prior to maximum catches (see positive anomalies in Figure $7 d$ ) than in the period prior to minimum catches (Fig. 7b, f). Again, the low-level atmospheric dynamics during periods of minimum catches is characterized by more intense mixture (Fig. 5d) and offshore wind-induced Ekman transport (Fig. 5b). Assuming that there is some sort of natural balance between biological and climatic processes, it can be argued that the increased (reduced) mixing concentrated in the northern portion of the SBB and its influence on the dispersion (retention) of larvae is actually a consequence of the thermodynamic adjustment between the ocean and the atmosphere. Robertson and Mechoso (2000) also found evidence of an interdecadal component with a 15 - to 17 -yr period in the leading mode of principal component of the high level $(200 \mathrm{hPa})$ atmospheric circulation and SST over the southwest Atlantic between $20^{\circ}$ and $30^{\circ} \mathrm{S}$.

According to the composite and case study results, in December and January prior to the maximum catches the atmosphere showed signs of a major presence of SACZ and frontal systems over the southwest Atlantic. Quadro (1994) mentioned that the passage of frontal systems could contribute to the formation, support and intensification of the SACZ precipitation band. In the zonal wind composite at $250 \mathrm{hPa}$ (Fig. 6a), the positive anomalies identified in the subtropical jet position indicate that this system was more intense and this is also an indicator of increased SACZ activity (Kodama, 1992, 1993) and cloudiness (Silva and Gandu, 1996). Apparently, the $250 \mathrm{hPa}$ geopotential anomalies for the minimum catch case study (Fig. 8c) tend to be positive, but it is not possible to relate these to the SACZ intensity. On the other hand, the atmospheric blocking observed in the geopotential height composite field at $850 \mathrm{hPa}$ related to the maximum catches (Fig. 6c) can also intensify the SACZ because this system makes the atmospheric frontal systems remain stationary and active for longer periods.

The present research has built on the results of Bakun and Parrish (1990), who studied the climatology of the SBB focusing on the reproductive habitat of the Brazilian sardine. We present an improved analysis on three different aspects. First, we include better-quality and new data to the suite of oceanic and atmospheric fields, such as geopotential height, OLR, PPT and $250 \mathrm{hPa}$ winds. Second, we adopt an explicit processoriented approach by looking for possible relations between oceanic and atmospheric variability during the spawning season and the increase or collapse of the Brazilian sardine production one year later. Third, we detect important meridional patterns observed in the climatologies associated with extreme events of the Brazilian sardine catches and establish their thermodynamic linkages. Bakun and Parrish (1990) argued that the reproductive strategy of the Brazilian sardine has developed so that spawning occurs in a stable and enriched environment with a high likelihood of larva retention. However, we contend that the quality of the spawning habitat and the interannual catch variability are likely to be a consequence of specific oceanatmosphere linkages rather than the sole choice of a stable environment. There is strong evidence indicating that the spawning habitat expands and contracts along the SBB according to the interannual variability of the horizontal and vertical mesoscale structure of the ocean (Gigliotti et al., 2010). Also, our results on wind stress, Ekman transport and mixing index show a better representation of the contrasts between the southern and northern SBB sectors (Fig. 3). Although the wind plays an important role in setting the conditions for the survival of the Brazilian sardine by controlling the surface water transport and vertical mixing, it is in fact responding to specific SACZ configurations.

Recently, Gigliotti et al. (2010) established for the first time the spawning habitat of the Brazilian sardine on the basis of survey data, spatial modelling and a 23-year-long SST time series from satellite data. Spawning areas are mostly coastal, with the largest one located to the south of the SBB and the patches becoming smaller to the northeast. Shelf width and mesoscale ocean dynamics play an important role in limiting the availability of suitable areas for massive spawning, which is less frequent at the northern limit of the SBB. Suitable spawning sites are provided by the entrainment of the colder and less-saline SACW onto the shelf due to the combined effect of coastal wind-driven and meander-induced upwelling. The predominant northeastern wind at the SBB and the resulting offshore surface Ekman transport, along with SSTA, bottom topography, coastline geometry and the Brazil Current meanders are all important factors that influence the reproductive success of the Brazilian sardine along different space-time scales.

Nevertheless, the high Ekman transport and mixing index identified in the north SBB during the spawning period previous to the minimum catches (Figs. 5 and 7 ) agree with the discussion presented in Bakun and Parrish (1990) and Bakun (1998). These authors mentioned that an excess of mixing and transport in the first stages of life could cause the dispersion of eggs and larvae, and that an environment with high mixing could reduce the probability of individuals encountering food particles. Previous studies have also shown the importance 
of spawning quantity and wind intensity to the survival in the initial stages of live. Jablonski and Legey (2004) discussed the importance of SST and wind intensity to the success of Brazilian sardine recruitment, but cited the quantity of spawning as the most important factor. They argue in favour of an optimum interval of wind intensity, between 3 and $4.5 \mathrm{~m} \mathrm{~s}^{-1}$, as stronger winds could disrupt plankton distribution and reduce larva survival. Evidence presented here for the relation between the thermodynamic control of the ocean-atmosphere system in the SBB with extreme variations in the production of the Brazilian sardine points to a larger and more complex interaction than envisaged before.

\section{CONCLUSIONS}

The results presented here show strong evidence of the linkage between extreme events of Brazilian sardine catches and the ocean-atmosphere interaction in the southwest Atlantic. The composite and case study analyses revealed that the system can be characterized by cooler SSTA along the SBB as a response to increased cloud cover and reduced incidence of shortwave radiation predominating one year before the Brazilian sardine catch maxima. This system can assume a different configuration in which positive SSTA condition over the SBB is associated with a less intense SACZ displaced southwards one year before the period of catch minima.

Previous studies have argued that the reproductive strategy of the Brazilian sardine has developed so that spawning occurs in a stable and enriched environment with a high likelihood of larva retention. Our results indicate that the spatial structure of the spawning habitat is a consequence of specific ocean-atmosphere interactions rather than the sole choice of a stable environment, and that this structure strongly influences the interannual variability of Brazilian sardine production.

Finally, the observed relation between the thermodynamic control of the ocean-atmosphere system in the SBB and the extreme variations in the production of Brazilian sardine points to a larger and more complex interaction than was envisaged before. The southwestern Atlantic Ocean is a region of cyclone generation and intensification where surface ocean conditions modulate the atmospheric boundary layer (Pezzi et al., 2009, Acevedo et al., 2010) and an important site for the understanding of South American weather and climate variability. A better understanding of the oceanic and atmospheric influences on the complete life cycle of the Brazilian sardine is still a challenge, but the present study offers a substantial contribution and improvement to the understanding of this complex system.

\section{ACKNOWLEDGEMENTS}

We thank Ilana Wainer, Mary Toshie Kayano and Carlos Frederico de Angelis for the scientific discussions. Two anonymous reviewers provided comments, which led to substantial improvements to this study. Helena C. Soares was funded by CAPES, Brazil. This is also a second author contribution for the CNPq (PQ) project number 306670/2006-2.

\section{REFERENCES}

Acevedo, O.C., L.P.Pezzi, R.B. Souza, V. Anabor and G.A. Degrazia. -2010 . Atmospheric boundary layer adjustment to the synoptic cycle at the Brazil Malvinas Confluence, South Atlantic Ocean. J. Geophys. Res., 115: D22107, doi:10.1029/2009JD013785.

Adler, R.F., G.J. Huffman, A. Chang, R. Ferraro, P. Xie, J. Janowiak, B. Rudolf, U. Schneider, S. Curtis, D. Bolvin, A. Gruber, J. Susskind, P. Arkin and E. Nelkin. - 2003. The Version 2 Global Precipitation Climatology Project (GPCP) Monthly Precipitation Analysis (1979-Present). J. Hydrom., 4(6): 1147-1167.

Bakun, A. - 1998. Ocean triads and radical interdecadal variation: bane and boon to scientific fisheries management. In: T.J. Pitcher, P.J.B. Hart. and D. Pauly (eds), Reinventing Fisheries Management, pp. 332-358. Kluwer Academic Publishers, London.

Bakun, A. and R.H. Parrish. - 1990. Comparative studies of coastal pelagic fish reproductive habitats: the Brazilian sardine (Sardinella aurita). J. Cons. Int. Mer., 46: 269-283.

Brambilla, M.C.V., N.J. Ferreira and H.F. Campos Velho. - 2004. Padrão de verão: ZCAS-VCAN atuando sobre a região sudeste do Brasil. In: XIII Congresso Brasileiro de Meteorologia, Fortaleza. http://www.cbmet.com/index.php. Data access: 15 mar. 2009.

Campos, J.D., D. Velhote and I.C.A. Silveira. - 2000. Shelf break upwelling driven by Brazil Current cyclonic meanders. Geophys. Res. Lett., 27(6): 751-754.

Carton, J. and B.S. Giese. - 2005. SODA: A reanalysis of Ocean Climate. J. Geophys. Res. C. http://cdc.cma.gov.cn/download/ refdoc/SODA \%20A\%20Reanalysis\%20of\%20Ocean\%20 Climate.pdf. Data access: 13 jul. 2009.

Carvalho, L.M., C. Jones and B. Liebmann. - 2004. The South Atlantic Convergence Zone: Intensity, form, persistence, and relationships with intraseasonal to interannual activity and extreme rainfall. J. Clim., 17: 88-108.

Castro, B.M. and L.B. Miranda. - 1998. Physical oceanography of western Atlantic continental shelf located between $4^{\circ} \mathrm{N}$ and $34^{\circ}$ S. In: A. R. Robinson and K. H. Brink (eds.), The Sea, pp. 209251. John Wiley \& Sons, Oxford.

Cavalcanti, I.F.A. and V.E. Kousky. - 2009. Frentes frias sobre o Brasil. In: I.F.A. Cavalcanti, N.J. Ferreira, M.G.A. Justi Da Silva, M.A.F. Silva Dias (eds.), Tempo e Clima, pp. 135-147. Oficina de Textos, São Paulo.

Cergole, M.C. - 1995. Stock assessment of the brazilian sardine, Sardinella brasiliensis, of the southeastern coast of Brazil. Sci. Mar., 59: 597-610.

Cergole, M.C., S.A. Saccardo and C.L.D.B. Rossi-Wongtschowski. -2002 . Fluctuation in the spawning stock biomass and recruitment of the brazilian sardine (Sardinella brasiliensis): 19771997. Revista Brasileira de Oceanografia., 50: 13-26.

Cergole, M.C. and C.L.D.B. Rossi-Wongtschowski. - 2005. Sardinella Brasiliensis (Steindachner, 1879). In: M. C. Cergole, A. O. Ávila-Da-Silva, C. L. D. B. Rossi-Wongtschowski (eds.), Análise das principais pescarias comerciais da região SudesteSul do Brasil: dinâmica populacional das espécies em explotação. IOUSP, São Paulo.

Chaves, R.R. and P. Nobre. - 2004. Interactions between the South Atlantic Ocean and the atmospheric circulation over South America. Geophys. Res. Lett., 31: 1-4.

Cury, P. and C. Roy. - 1989. Optimal environmental window and pelagic fish recruitment success in upwelling areas. Can. J. Fish. Aquat. Sci., 46: 670-680.

Doyle, M.E. and V.R. Barros. - 2002. Midsummer low-level circulation and precipitation in subtropical South America and related sea surface temperature anomalies in the South Atlantic. J. Clim., 15: 3394-3410.

Fuentes, M.V. - 1996. Bloqueios. Climanálise. INPE. São José dos Campos. http://climanalise.cptec.inpe.br/ rclimanl/boletim/ cliesp10a/bloqueio.html. Data access: 03 mar. 2010.

Gigliotti, E.S., D.F.M. Gherardi, E.T. Paes, R.B. Souza and M. Katsuragawa. - 2010. Spatial analysis of egg distribu- 
tion and geographic changes in the spawning habitat of the Brazilian sardine Sardinella brasiliensis. J. Fish. Biol., doi:10.1111/j.1095-8649.2010.02802.x.

Jablonski, S. and L.F.L. Legey. - 2004. Quantifying environmental effects on the recruitment of Brazilian sardine (Sardinella brasiliensis), 1977-1993. Sci. Mar. 68: 385-398.

Justi Da Silva, M.G.A. and M.A.F. Silva Dias. - 2002. A freqüência de fenômenos meteorológicos na América do Sul: uma climatologia. In: XII Congresso Brasileiro de Meteorologia, Foz de Iguaçu-PR, http://www.cbmet.com/index.php. Data access: 22 mai. 2009.

Kayano, M.T. and V.E. Kousky. - 1990. Southern Hemisphere blocking: a comparison between two indices. Meteorol. Atmos. Phys., 42: 165-170.

Kayano, E. - 1999. Southeastern Pacific blocking episodes and their effect on South American Weather. Met.Atmos. Phys., 69: $145-155$.

Kodama, Y-M. - 1992. Large Scale Common Features of Subtropical Precipitation Zones (the Baiu Frontal Zone, the SPCZ, and the SACZ). Part I: Characteristics of Subtropical Frontal Zones. J. Meteorol. Soc. Jpn., 70(4): 813-841.

Kodama, Y-M. - 1993. Large-Scale Common Features of Subtropical Precipitation Zones (the Baiu Frontal Zone, the SPCZ, and the SACZ). Part II: Conditions of the circulations for generating the STCZs. J. Meteorol. Soc. Jpn., 71(5): 581-610.

Lasker, R. - 1975. Field criteria for survival of Anchovy Larvae: The relation between inshore chlorophyll maximum layers and successful first feeding. Fish. Bull., 73(3): 453-462.

Lejenäs, H. - 1984. Characteristics of southern hemisphere blocking as determined from a time series of observational data. $Q$. $J$. Roy. Meteor. Soc., 110: 967-979.

Liebmann, B. and C.A. Smith. - 1996. Description of a Complete (Interpolated) Outgoing Longwave Radiation Dataset. B. Am. Meteorol. Soc., 77(6): 1275-1277.

Matsuura, Y. - 1996. A probable cause of recruitment failure Sardinella Aurita population during the 1974/75 spawning season. $S$. Afr. J. Mar. Sci., 17: 29-35.

Paes, E.T. and L.E.S. Moraes. - 2007. A new hypothesis on the influence of the El Niño/La Niña upon the biological productivity, ecology and fisheries of the Southern Brazilian Bight. PanamJAS., 2: 94-102.

Pezzi, L.P. and I.F.A. Cavalcanti. - 1994. O jato subtropical sobre a América do Sul no período de 1980 a 1989. Anais do VIII Congresso Brasileiro de Meteorologia.

Pezzi, L.P., R.B. Souza, O. Acevedo, I. Wainer, M.M. Mata, C.A.E. Garcia and R. Camargo. - 2009. Multiyear measurements of the oceanic and atmospheric boundary layers at the BrazilMalvinas confluence region. J. Geophys. Res., 114: D19103.

Pezzi, P.L. and R.B. Souza. - 2009. Variabilidade de mesoescala e interação oceano-atmosfera no Atlântico Sudoeste. In: I.F.A. Cavalcanti, N.J. Ferreira, M.G.A. Justi Da Silva, M.A.F. Silva Dias (eds.), Tempo e Clima, pp. 385-405. Oficina de Textos, São Paulo.

Quadro, M.F.L. - 1994. Cases study of the South Atlantic Conver- gence Zone (SACZ) over the South America. Msc thesis, Instituto Nacional de Pesquisas Espaciais.

Quinn, T.J. and R.B. Deriso. - 1999. Quantitative Fish Dynamics. Oxford, University Press, New York.

Ramírez, V., M.T. Kayano and N.J. Ferreira. - 1999. Statistical analysis of upper tropospheric vortices in the vicinity of northeast Brazil during the 1980-1989. Atmosféra, 12(2): 75-88.

Robertson, A.W. and C.R. Mechoso. - 2000. Interannual and interdecadal variability of the South Atlantic convergence zone. Mon. Weather. Rev., 128: 2947-2957.

Rodrigues, R.R. and J.A. Lorenzzetti. - 2001. A numerical study of the effects of bottom topography and coastline geometry on the Southeast Brazilian coastal upwelling. Cont. Shelf. Res., 21: 371-394.

Saccardo, S.A. and C.L.D.B. Rossi-Wongtschowski. - 1991. Biologia e avaliação do estoque da sardinha Sardinella Brasiliensis: Uma compilação. Atlântica., 13: 29-4.

Silva, W.B. and A.W. Gandu. - 1996. Análise diagnóstica do jato subtropical, durante a evolução da Zona de Convergência do Atlântico Sul. In: I Simpósio de Iniciação Científica do IAGUSP. São Paulo.

Sinclair, M. - 1988. Marine populations: an essay on population regulation and speciation. Univ. Washington Press, Seattle.

Sinclair, M.R. - 1996. A climatology of anticyclones and blocking for the southern hemisphere. Mon. Weather. Rev., 124: 245-262.

Smith, T.M., R.W. Reynolds, T.C. Peterson and J. Lawrimore. 2008. Improvements to NOAA's Historical merged Land Ocean surface temperature analysis (1880-2006). J. Clim., 21: 2283-2296.

Sunyé, P.S. and J. Servain. - 1998. Effects of seasonal variations in meteorology and oceanography on the Brazilian sardine fishery. Fish. Oceanogr., 7: 89-100.

Trenberth, K.E and K.C.Mo. - 1985. Blocking in the southern hemisphere. Mon. Weather. Rev., 113: 3-21.

Uppala, S.M., P.W. Kallberg, A.J. Simmons, U. Andrae, V.D. Bechtold., M. Fiorino., J.K. Gibson, J. Haseler, A. Hernandez., G.A. Kelly, X. Li., K. Onogi, S. Saarinen, N. Sokka, R.P. Allan, E. Andersson, K. Arpe, M.A. Balmaseda, A.C.M. Beljaars, L. Van De Berg, J. Bidlot, N. Bormann, S. Caires, F. Chevallier, A. Dethof, M. Dragosavac, M. Fisher., M.V. Fuentes, S. Hagemann, E. Hólm, B.J. Hoskins, L. Isaksen, P.A.E.M. Janssen, R. Jenne, A.P. Mcnally, J.F. Mahfouf, J.J. Morcrette, N.A. Rayner, R.W. Saunders, P . Simon, A. Sterl, K.E. Trenberth, A. Untch, D. Vasiljevic, P. Viterbo and J. Woollen. - 2005. The ERA-40 reanalysis. Q. J. Roy. Meteor. Soc., 131(612): 2961-3012.

Van Loon, H. - 1956. Blocking action in the southern hemisphere. Part I. Notos., 5: 171-177.

Virji, H. - 1981. A preliminary study of summertime tropospheric circulation patterns over South America estimated from cloud winds. Mon. Wea. Rev., 109: 599- 610.

Scient. ed.: I. Palomera.

Received July 8, 2010. Accepted March 1, 2011.

Published online August 22, 2011. 